\title{
Is Input Utilization Inelastic to Coffee Production
}

\author{
Nurhapsa $^{1 *}$, Andi Nuddin ${ }^{2}$, Suherman ${ }^{3}$, Betrixia Barbara ${ }^{4}$ \\ ${ }_{1}^{1}$ Agribusiness Study Program, Graduate Program, Universitas Muhammadiyah Parepare, Indonesia. \\ ${ }^{2}$ Agribusiness Study Program, Graduate Program, Universitas Muhammadiyah Parepare, Indonesia. \\ ${ }^{3}$ Agrotechnology Study Program, Faculty of Agriculture, Animal Husbandry and Fisheries, Universitas \\ Muhammadiyah Parepare, Indonesia. \\ 4 Social Economy Study Program, Faculty of Agriculture, University of Palangka Raya, Indonesia. \\ *Corresponding author's e-mail: hapsa_faktan@yahoo.co.id
}

How to Cite: Nurhapsa, Nuddin, A., Suherman, Barbara, B. (2020). Is Input Utilization Inelastic to Coffee Production. Int. J. Agr. Syst. 8(1): 26-33

\begin{abstract}
The agricultural sector is one of the important sectors for the Indonesian economy. Coffee is one of the commodities produced from the plantation sub-sector included in the agricultural sector which also contributes greatly to the Indonesia economy, especially as a source of foreign exchange, employment and income sources as well as other economic actors. This study aims to determine whether the factors of land area production, number of productive trees, farming costs and labour used by coffee farmers are elastic or inelastic to coffee production. Samples were taken as many as 400 coffee farmers spread in four districts namely North Toraja Regency, Enrekang Regency, Sinjai Regency and Bantaeng Regency, South Sulawesi, Indonesia. Data collected in the form of primary data and secondary data. The analysis used the Cobb-Douglass production function. The results show that the use of production factors; land area, number of productive trees, farming costs and labor are inelastic to coffee production, the scale of farming follows the rules of increasing return to scale. Therefore, it is expected that the support of local government (related institutions) to assist coffee farmers in providing superior seeds to increase coffee production, farmers incomes and reduce land conversion.
\end{abstract}

Copyright @2020 IJAS. All rights reserved.

\section{Keywords:}

Elasticity; production input; coffee production; cobb-douglass

\section{Introduction}

The agricultural sector is one sector that contributes to the Indonesian economy. This is due to the agriculture sector giving the second largest contribution to the National GDP after the manufacturing sector. In addition, the agricultural sector also contributes to the provision of employment, provision of raw materials for special industries of the food and beverage industry (Nurhapsa, 2013). Coffee is one of the commodities produced from the plantation sub-sector included in the agricultural sector which also contributes greatly to the Indonesian economy, especially as a source of foreign exchange, employment, and income sources as well as other economic assistance. Coffee is a commodity cultivated by farmers in Indonesia where there are two types of coffee that are cultivated, Arabica coffee and Robusta coffee. This is because coffee is a 
promising commodity and an export commodity. According to Yordy (2017) the value of Indonesia's coffee exports in 2014 amounted the US \$ 588,329,553.00.

South Sulawesi Province is one of the provinces in Indonesia which is the center of coffee production. Arabica coffee is a type of coffee that is widely cultivated by coffee farmers in South Sulawesi Province. Several districts in South Sulawesi Province which are free coffee production centers in Enrekang Regency. North Toraja Regency, Sinjai Regency, and Bantaeng Regency. Data from the South Sulawesi Provincial Plantation Office shows that the amount of Arabica coffee production from 2010-2014 used fluctuations. Arabica coffee production increased in 2010 by 21,798 tons, and in the following year, Arabica coffee production increased. Some factors that cause low coffee production include: (1) the use of seeds that are not superior; (2) plants that are old and have never been rejuvenated; (3) sub optimal maintenance. This shows the need for government contribution to increasing coffee production considering that this commodity is an export commodity or demand for coffee is mostly very large Arabica coffee (Yordy, 2017).

Based on the microeconomic theory that the production process is a combination of processes and materials in the manufacture of goods and services. In the microeconomic theory called the production function which shows the relationship between factors of production (input) with the level of production produced (output). The commodity production process can be carried out by external and internal factors, including Arabica coffee production. External factors that cannot be changed by humans can consist of climate, namely rainfall which will affect plant growth and harvest. While internal factors that can be used by humans include the use of production inputs such as land area, number of productive trees, farming costs and labor use.

Generally, farmers have limited capital capacity. Farmers who have limited capital affect the risk behavior of farmers and the number of factors of production owned. The results of Syafa'at's research (1990) show that owner and tenant farmers are risk enthusiasts in the use of inorganic fertilizers while pawn farmers act as risk aversion in the use of inorganic fertilizers. Farmer risk behavior will affect the number of factors that affect the level of production and the level of income of farmers. The factor of production which is also known as the determining factor in the production process. According to Sukirno (1994) the factors of production consist of labor, capital, land and entrepreneurial expertise. The production factors used by coffee farmers are the area of land, the number of productive trees, the cost of farming and labor. This study aims to determine the elasticity of the use of coffee production inputs to coffee production in South Sulawesi Province.

\section{Materials and Methods}

The study was conducted in four districts that became centers of coffee production, namely Enrekang Regency, North Toraja Regency, Sinjai Regency and Bantaeng Regency, South Sulawesi, Indonesia. Each district was sampled with differen amounts and selected by simple random method. The number of samples taken in Enrekang Regency were 171 coffee farmers, North Toraja Regency were 79 coffee farmers, Sinjai Regency were 80 coffee farmers and Bantaeng Regency were 70 coffee farmers. The total sample taken was 400 coffee farmers. The data collected consists of primary data in the form of data about the identity of coffee farmers, coffee farming data and secondary data in the form of data on production and productivity, area of coffee land 
in each district and other data related to this study. Data were analyzed with the CobbDouglass production function as follows:

$$
\begin{aligned}
& Y=a X 1^{\beta 1} X 2^{\beta 2} X 3^{\beta 3} X 4^{\beta 4+u i} \\
& \text { Where: } \\
& \text { Y }=\text { Coffee production (kg) } \\
& \beta 1, \beta 2, \beta 3, \beta 4=\text { Regression coefficients } X 1, X 2, X 3, X 4 \\
& \text { X1 = Land area (hectare) } \\
& \text { X2 = Number of productive trees (trees) } \\
& \text { X3 = Farming Cost (IDR) } \\
& \quad X 4=\text { Labor (HOC) } \\
& \text { Ui }=\text { Error } \\
& \operatorname{Ln} Y=\operatorname{Ln} a+\beta_{1} \operatorname{Ln} X_{1}+\beta_{2} \operatorname{Ln} X_{2}+\beta_{3} \operatorname{Ln} X_{3}+\beta_{4} \operatorname{Ln} X_{4}+u_{i}
\end{aligned}
$$

By using the Cobb-Douglas production function, the regression coefficient of the regression coefficient reflects the value of production elasticity (Ep). The criteria for elasticity are (Soekartawi, 1994):

1. If the value of $E p>1$, the production process is in the region I

2. If the value of $0<\mathrm{Ep}<1$, the production process is in area II

3. If the value of $E p<1$, the production process is in region III

\section{Results and Discussion}

\subsection{Profile of Coffee Farmers}

\subsubsection{Age of Farmers}

Farmers' productivity and work skills are needed by older farmers. According to Nurhapsa, et al (2017) as age increases, productivity, and workability also increase, and will further increase productivity and workability improvement at a certain age. In addition, the ability to think, thinking maturity is also a physical ability, also thinking by age. Furthermore, Jumiati, et al (2014) stated that young and healthy farmers have stronger power compared to older farmers. Distribution of farmers by age shown in Table 1.

Table 1. Distribution of Farmers Answering by Age

\begin{tabular}{ccc}
\hline Age (Year) & Amount (Person) & Percentage (\%) \\
\hline $21-25$ & 5 & 1.25 \\
$26-30$ & 35 & 8.75 \\
$31-35$ & 27 & 6.75 \\
$36-40$ & 55 & 13.75 \\
$41-45$ & 73 & 18.25 \\
$46-50$ & 75 & 18.75 \\
$51-55$ & 76 & 19.00 \\
$56-60$ & 27 & 6.75 \\
$>60$ & 27 & 6.75 \\
\hline Total & $\mathbf{4 0 0}$ & $\mathbf{1 0 0}$ \\
\hline
\end{tabular}


Table 1 describes the coffee farmers who were respondents in this study amounted to 93.25 percent and 6.75 percent were classified as unproductive. This result means that the respondent farmers still have physical abilities, thinking abilities and thinking maturity that is good enough to support optimal. This contradicts research conducted by Istianah, et al (2015) which shows that coffee farmers in Jambu District, Semarang Regency are still relatively old so they are still strong and still developing to develop in order to be able to and produce maximum production or yield. Farmer age is a key role in increasing production because it influences their decisions. according to Mojo et al (2017), that increasing age affects the probability of farmers' decisions in doing business.

\subsubsection{Educational Level of Farmers}

Furthermore, it can consider the level of education of farmers. Respondents were quite varied, starting from those who did not graduate from elementary school by 6 people $(1.50 \%)$, elementary schools by 182 people (45.50\%), junior high schools by 111 $(27.75 \%)$, high schools by $19,25 \%$ and Diploma/Bachelor Degree by 24 people $(6.00 \%)$. The results indicate that a fraction of farmer have diploma/bachelor degree. The results of the study by Istianah et al (2015) showed that coffee farmers in Jambu Subdistrict, Semarang Regency had a low level of education, namely primary school at 73.91 percent (51 people) from 69 farmers. Table 2 show that the level of education of the respondent farmer is the length of the farmer in the course of education. Farmer education level has an important role in policy making as well as the risks faced. Farmer origin education is an influential and promising variable in taking action (Binam et al, 2003).

Table 2. Distribution of Farmers by Level of Education

\begin{tabular}{lcc}
\hline \multicolumn{1}{c}{ Education Level (Years) } & Amount (Person) & Percentage (\%) \\
\hline Not completed in primary school & 6 & 1.50 \\
Primary school & 182 & 45.50 \\
Junior high school & 111 & 27.75 \\
Senior High School & 77 & 19.25 \\
Diploma/Bachelor Degree & 24 & 6.00 \\
\hline \multicolumn{1}{c}{ Total } & $\mathbf{4 0 0}$ & $\mathbf{1 0 0 . 0 0}$ \\
\hline
\end{tabular}

\subsubsection{Coffee Farming Experience of Respondent Farmers}

The experience of coffee farming is the respondent of farmers in conducting coffee farming activities. The results of the study Nurhapsa, et al (2017) show that farming experience is one of the determining factors in the success of a farm. Based on the distribution of farmers by experience of coffee farming shown in Table 3. The majority of farmers had the experience of coffee farming over 5 years which amounted to 97.5 percent. This shows that the respondent farmers have a long experience of coffee farming. With this experience, farmers accept and choose the innovations they need in coffee farming. The long experience of farming owned by farmers is an experience for them in adopting innovations based on their needs (Nurhapsa et al, 2018). 
Table 3. Distribution of Farmers by Farming Experience

\begin{tabular}{ccc}
\hline Farming Experiencei (Years) & Amount (Person) & Percentage (\%) \\
\hline $1-5$ & 11 & 2.75 \\
$6-10$ & 44 & 11.00 \\
$11-15$ & 35 & 8.75 \\
$16-20$ & 101 & 25.25 \\
$>20$ & 209 & 52.25 \\
\hline Total & $\mathbf{4 0 0}$ & $\mathbf{1 0 0}$
\end{tabular}

\subsubsection{The Coffee and Area of Farmers}

Based on production theory, one of the inputs that determine output is land resources. Distribution of farmers based on the area of land managed shown in Table 4. It was found that 85.50 percent of the respondent farmers who own land of $0.10-1.00$ hectare. This shows that the area of coffee owned by farmers is relatively narrow so that it can be one of the obstacles in increasing coffee production capacity. In addition, increasing other production increases the number of relatively less productive plants quite a lot. Land area determines the number of trees planted, so the area of land is considered to affect coffee production. To increase production, it is very necessary to expand the area of land planted by farmers (Arsyad et al, 2014). This shows that farmers have a responsibility to adopt the best and most profitable farming practices (Dagos, 2019).

Table 4. Distribution of Farmers by Land Area.

\begin{tabular}{ccc}
\hline Land Area (hectare) & Amount (Person) & Percentage (\%) \\
\hline $0.10-0.50$ & 182 & 45.50 \\
$0.51-1.00$ & 159 & 39.75 \\
$1.10-1.50$ & 41 & 10.25 \\
$1.51-2.00$ & 14 & 3.50 \\
$>2.00$ & 4 & 1.00 \\
\hline Total & $\mathbf{4 0 0}$ & $\mathbf{1 0 0 . 0 0}$ \\
\hline
\end{tabular}

\subsection{Profile of Coffee Farmers}

According to Murti et al. (2015) declare the elasticity of production is the degree of sensitivity of production or respect the response variable if there is a change in the independent variable. By using the Cobb-Douglas production function, the value of production elasticity from the regression coefficients of each independent variable used in the equation. The results of data analysis using SPSS version 21 software shown in Table 5.

Table 5 show $\mathrm{R}^{2}$ value of 0.632 indicate that the proportion of changes in the $\mathrm{Y}$ variable (coffee production) determined by the independent change variable (production factor) is $63.2 \%$ and the remaining $36.8 \%$ is determined by the variable based on the equation or model. Simultaneously variable land area, number of productive trees, farming costs and labor have a significant effect on coffee production. The value of the regression coefficient of each variable with the production elasticity of the variables used in the production function equation. The regression coefficient value of the land area variable is 0.381 . This shows that the land area of 1 percent with other factors fixed (ceteris paribus) will increase coffee production by 0.381 percent. Inelastic critical land area, this impact shows that each large land has not contributed greatly to the amount of 
coffee production. Land that is well managed will give good results and vice versa if the land is not well managed, the results obtained are also not good. In addition, ecological aspects also play an important role in the development and production of coffee (Saragih, 2013).

Table 5. Factors Affecting Coffee Production

\begin{tabular}{lc}
\hline \multicolumn{1}{c}{ Description } & Estimated Parameter \\
\hline Constant & -0.841 \\
Ln X1 (Land Area) & $0.381^{*}$ \\
Ln X2 (Number of productive trees) & $0.341^{*}$ \\
Ln X3 (farming costs) & $0.293^{*}$ \\
Ln X4 (Labor) & $0.123^{*}$ \\
$\mathrm{R}$ & 0.632 \\
$\mathrm{R}^{2}$ & 0.628 \\
$\mathrm{~F}$ & $169.274^{*}$ \\
\hline \multicolumn{2}{r}{ Total } \\
\hline
\end{tabular}

Notes: *significant $<0.05$

Variable number of coffee plants that produce a regression coefficient of 0.341 which means the number of productive plants increases 1 percent will increase the amount of coffee production by 0.341 percent assuming other factors remain. The increasing number of productive coffee trees will increase the amount of coffee production. The variable number of productive trees has an elasticity value of 0.341 which indicates the variable number of productive trees is not elastic. The results of this study compare with research conducted by Indra (2011) which shows the number of coffee trees that produce significantly to people's coffee production in Central Aceh District. The results of this study also showed that the method of using work in smallholder coffee farms in Central Aceh District was also inefficient. In line with research conducted by Sharma et al. (2015) on the economic aspects of Arabica coffee production in the Parbat District, Nepal relating to the number of productivity trees to the amount of Arabica coffee production in Nepal.

The farm cost variable has a regression coefficient of 0.293 . These results indicate that if farming costs increase by 1 percent it will increase coffee production by 0.293 percent with the assumption of ceteris paribus. The variable of farming costs is not elastic which shows that each variable of farming costs is not too large to contribute to the amount of coffee production produced by farmers. Labor variable has a regression coefficient of 0.123 which indicates that labor increases by 1 percent will increase coffee production by 0.123 percent assuming other factors do not increase change. The results of this study reverse the research conducted by Jumiati, et al (2014) showing that outpouring of labor in coffee farming in Tana Tidung Regency has a significant effect on coffee production. The Labor variable is also inelastic which means that each Labor variable does not contribute too much to the amount of coffee produced.

According to Soekartawi (2002) hat the value of Return To Scale (RTS) needs to be verified to be able to explain whether farming activities carried out follow the rules of increasing, constant or decreasing back to scale with the following criteria:

a. If the value $\beta 1+\beta 2+\ldots+\beta n>1$, the Increasing Return To Scale which shows that the proportion of the addition of production factors will produce additional production of a greater proportion. 
b. If the value $\beta 1+\beta 2+\ldots+\beta n=1$ then Constant Return To Scala which shows that the proportion of the addition of production factors will produce additional production with the same proportion.

c. If the value of $\beta 1+\beta 2+\ldots+\beta n<1$ then Decreasing Return To Scale which shows that the proportion of the addition of production factors will produce additional production with a smaller proportion.

The RTS value of 1.138 is obtained from the sum of the regression coefficients of the independent variables used in the equation. These results indicate that the proportion of the addition of production factors will produce additional production with a greater proportion. Production activities shows that there is still a need to increase the use of production factors to increase coffee production in South Sulawesi.

\section{Conclusion}

The use of production factors of land area, number of productive trees, farming costs and labor in coffee farming is classified as elastic and the scale of coffee farming in follows the Increasing Return To Scale (IRTS). The need for local government support (related agencies) to help coffee farmers in the provision of superior seeds to increase coffee production, farmers' incomes and reduce land conversion.

\section{Acknowledgements}

We would like to thank DRPM DIKTI for providing funding to carry out research activities in 2019. We also thank the Rector of Universitas Muhammadiyah Parepare, Dean of the Faculty of Agriculture, Animal Husbandry and Fisheries, Chair of the Research Institute and Community Services (LPPM) Universitas Muhammadiyah Parepare for all the instructions and assistance in conducting the research.

\section{References}

Arsyad, M., Nuddin, A., Zamhuri, M. Y., \& Yusuf, S. (2014). The Poverty Reality of Coastal and Agriculture: How Severe the Seaweed Farmers and Cocoa Smallholders Are?. International Journal of Agriculture System, 2(2), 119-131.

Binam, J. N., Sylla, K., Diarra, I., \& Nyambi, G. (2003). Factors affecting technical efficiency among coffee farmers in Cote d'Ivoire: Evidence from the centre west region. African Development Review, 15(1), 66-76.

Dagos, R. A. T. (2019). Assessment of lowland rice-based organic farming in selected municipalities of Occidental Mindoro, Philippines. International Journal of Agriculture System, 7(1), 79-88.

Indra. (2011). Penentuan Skala Usaha dan Analisis Efisiensi Ekonomi Usahatani Kopi Rakyat di Kabupaten Aceh Tengah. Jurnal Agrisep, 12(1):1-8.

Istianah, Hastuti, D., \& Prabowo, R. (2015). Faktor-faktor yang Mempengaruhi Tingkat Pendapatan Petani Kopi (Coffea sp) (studi Kasus di Kecamatan Jambu, Kabupaten Semarang). Jurnal Ilmu-ilmu Pertanian, 11(2):46-59.

Jumiati, E., \& Mulyani, S.I. (2014). Efisiensi Teknis Usahatani Kopi di Kabupaten Tana Tidung (KTT). Jurnal Agrifor, XIII(2):155 - 164.

Mojo, D., Fischer, C., \& Degefa, T. (2017). The determinants and economic impacts of membership in coffee farmer cooperatives: recent evidence from rural Ethiopia. Journal of Rural Studies, 50, 84-94. 
Murti, A.T., Hartono, B., \& Fanani, Z. (2015). Elastisitas Produksi Usaha Peternakan Broiler Pola Kemitraan di Kabupaten Blitar. J-PAL, .6(2):123-132.

Nurhapsa, Kartini, Arham, Arsyad, M., Suherman, \& Sirajuddin, S.N. (2017). Technical Eficiency of Onion (Allium cepa,L) Farming In Anggeraja Indonesia. Journal Entomologi and Applied Science Letter, 4(3):16-22.

Nurhapsa, N., Nuddin, A., Suherman, S., \& Lismayanti, L. (2018) Efisiensi Saluran Pemasaran Kopi Arabika di Kabupaten Enrekang. In Prosiding Seminar Nasional Sinergitas Multidisiplin Ilmu Pengetahuan dan Teknologi (Vol. 1, pp. 230-234).

Nurhapsa. (2013). Analisis Efisiensi Teknis dan Perilaku Risiko Petani Serta Pengaruhnya Terhadap Penerapan Varietas Unggul Pada Usahatani Kentang di Kabupaten Enrekang, Provinsi Sulawesi Selatan, Disertasi Doktor. Sekolah Pascasarjana, Institut Pertanian Bogor, Bogor.

Syafa'at, N. (1990). Faktor-faktor yang Mempengaruhi Efisiensi Teknis Relatif dan Sikap Petani dalam Menghadapi Risiko Produksi pada Usahatani Padi Sawah di Lahan Beririgasi Teknis. Jurnal Agroekonomi, 9 (2): 30 - 48

Saragih, J.R. (2013). Socioeconomic and Ecological Dimension of Certified and Conventional Arabica Coffee Production in North Sumatra, Indonesia. Asian Journal of Agriculture and Rural Development, 3(3):93-107.

Sharma, S., Dhakal, C.K., Ghimire, B., \& Rijal, A. (2015). Economic Significant of Coffee (Coffee Arabica) Production in Parbat District of Nepal. International Journal of Agricultural Management and Devolepment (IJAMAD), 6(2): 123 - 130.

Soekartawi. (1994). Teori Ekonomi Produksi Dengan Pokok Bahasan AnalisisFungsi Cobb-Douglas, CV Rajawali, Jakarta.

Soekartawi. (2002). Teori Ekonomi Produksi dengan Pokok Bahasan Analisis Fungsi Cobb-Douglas. PT. Raja Grafindo Persada, Jakarta.

Sukirno, S. 1994. Pengantar Teori Mikroekonomi. PT. Raja Grafindo Persada, Jakarta.

Yordy, G. (2017). Analisis Faktor-faktor yang Mempengaruhi Produksi Kopi Arabika di Provinsi Sulawesi Selatan. Skripsi. Departemen Ilmu Ekonomi, Fakultas Ekonomi dan Bisnis, Universitas Hasanuddin, Makassar. 